\title{
Pharmacological Therapy for Apathy in Alzheimer's Disease: A Systematic Review and Meta-Analysis
}

\author{
Amir A. Sepehry, Michael Sarai, Ging-Yuek R. Hsiung
}

\begin{abstract}
Introduction: Apathy is highly prevalent in Alzheimer's disease (AD), but whether pharmacotherapy is effective in managing apathy is unclear. Methods: To assess the efficacy of pharmacotherapy for apathy in AD we searched for randomized controlled trials (RCT) and aggregate data reporting on apathy in several search engines, reference lists of articles, and reviews. Demographic characteristics and relevant data were extracted to assess apathy. Results: Fifteen RCTs' were examined, and 11 were used in aggregate meta-analytic statistics. Drugs included were cholinesterase inhibitors, memantine, and psycho-stimulants. We found no significant treatment effect in favour of any of the drugs, and the effect-size estimates under a random effect model were heterogeneous. Most RCTs had a high attrition rate and used the NPI apathy subscale to measure apathy. Conclusion: The lack of an effect could be explained by methodological limitations, publication bias, and heterogeneity.
\end{abstract}

RÉSUMÉ: Traitement pharmacologique de l'apathie liée à la maladie d'Alzheimer: revue systématique et méta-analyse. Introduction: L'apathie est un état très courant chez les patients atteints de la maladie d'Alzheimer. Cela dit, on ignore encore dans quelle mesure la pharmacothérapie permet de le traiter de façon efficace. Méthodes: Afin d'évaluer l'efficacité des traitements pharmacologiques de l'apathie liée à la maladie d'Alzheimer, nous avons effectué une recension d'essais cliniques randomisés (ECR) et rassemblé, au moyen de plusieurs moteurs de recherche, de listes de référence d'articles clés et de recensions, des données concernant cet état. Des caractéristiques démographiques et d'autres données jugées pertinentes ont ensuite été extraites afin de mieux l'évaluer. Résultats: Au total, nous avons passé en revue quinze ECR ; onze d'entre eux ont été utilisés dans le cadre d'une méta-analyse agrégée. Parmi les médicaments inclus, on peut mentionner les inhibiteurs de cholinestérase, la mémantine et un certain nombre de psychostimulants. En gros, nous n'avons relevé aucun effet notable associé à la prise de ces médicaments. De plus, les estimations de l'ampleur des effets en vertu d'un modèle à effets aléatoires se sont révélées hétérogènes. Fait à noter, la plupart des ECR ont dû composer avec un taux d'abandon élevé et ont utilisé le Neuropsychiatric Inventory (NPI) pour mesurer l'apathie. Conclusions: L'absence d'effet pourrait s'expliquer par des contraintes méthodologiques, des biais de publication et une hétérogénéité statistique.

Keywords: Apathy, Pharmacological treatment, Alzheimer's disease, Review, Clinical trials

doi:10.1017/cjn.2016.426

Can J Neurol Sci. 2017; 44: 267-275

\section{INTRODUCTION}

Apathy, defined as the absence or lack of feeling, emotion, interest, concern, or motivation not attributable to cognitive impairment, emotional distress, or a decreased level of consciousness, is a common neuropsychiatric syndrome in Alzheimer's disease (AD). ${ }^{1}$ Apathy is seen to occur early in the clinical course of the illness and progresses in concert with declining cognitive function. ${ }^{2}$ Apathetic AD patients often have more rapid cognitive decline, ${ }^{3}$ and are more impaired on activities of daily living. ${ }^{4} \mathrm{Up}$ to $80 \%$ of $\mathrm{AD}$ patients experience some degree of apathy during the course of their illness, ${ }^{2}$ depending on the assessment scale, type of population studied, diagnostic criteria, and by type and severity of AD. ${ }^{5}$ Apathy tends to first appear in the prodromal stage of $\mathrm{AD},{ }^{6}$ and increases as the illness progresses from MCI to dementia along the spectrum of neurocognitive disorders (NCD). For example, one study showed a prevalence of $42 \%$ for mild, $80 \%$ for moderate, and $92 \%$ for advanced stages of $\mathrm{AD}^{2}$ In another cohort study of patients with probable $\mathrm{AD}$, apathy was associated with an increased risk of death. ${ }^{7}$ Despite its high prevalence, treatment of symptomatic apathy in $\mathrm{AD}$ has not been well studied.

\section{ASSESSMENT/DIAGNOSIS OF APATHY IN AD}

Proposed as an independent syndrome separate from depression, apathy symptoms are put into a set of diagnostic criteria that are now validated for use in $\mathrm{AD}$ and stroke. ${ }^{8-11}$ Robert and colleagues proposed that for diagnosing apathy in $\mathrm{AD},(1)$ the core feature of apathy (diminished motivation) must be present for at least four weeks; (2) two of the three dimensions of apathy (reduced goaldirected behavior, goal-directed cognitive activity, and emotions) must also be present; (3) there should be identifiable functional impairments attributable to apathy; and (4) criteria are specified to exclude symptoms and states that mimic apathy. ${ }^{12}$

From the University of British Columbia, Department of Medicine, Division of Neurology, Vancouver, Canada [AAS, GYRH]; College of Medicine, Kansas City University of Medicine \& Biosciences, Kansas City, USA [MS].

Received May 24, 2016. Final Revisions Submitted SePtember 9, 2016. Date of ACCEPTANCE SEPTEMBER 28, 2016.

Correspondence to: Ging-Yuek R. Hsiung, Division of Neurology, S152 - 2211

Wesbrook Mall, University of British Columbia, Vancouver BC, Canada V6T 2B5.

Email: hsiung@mail.ubc.ca 
A limitation of current data with the available diagnostic criteria is that most studies were performed prior to the development and validation of these criteria, which makes the evaluation of the evidence challenging. Nonetheless, most assessments of apathy in clinical samples use scales to measure the severity or to differentiate apathy from depression by excluding symptoms such as sadness and negative thoughts that are typically observed in depressive syndromes.

The Apathy Evaluation Scale (AES), a Likert-Like scale measure, was developed by Marin and colleagues. ${ }^{13}$ This measure consists of three sections (with 18 items each) and allows collection of information on the symptoms from an informant, the clinician, and the patient. A shorter version is adapted for nursing home patients. ${ }^{14}$ The Apathy Scale (AS), developed by Starkstein and co-workers, is an examiner-rated scale with 14 items based on the Marin's instrument. ${ }^{15}$ Robert and colleagues developed the Likert-style Apathy Inventory (AI) built on Marin and colleagues' diagnostic criteria for apathy. ${ }^{16}$ This 12 -item scale collects information from both the patient and the caregiver by "yes/no" responses, and deals with behavioral changes that have occurred since the beginning of the disease. The caregiver section is structured similarly to the Neuropsychiatric Inventory (NPI) ${ }^{17}$ such that when the caregiver response is negative, a score of zero is attributed and the rater proceeds to the next item. If the response is positive, frequency and severity of the items are explored. Strauss and Sperry developed the informant-based 16-item uni-dimensional Dementia Apathy Interview and Rating (DAIR) scale to assess apathy among individuals with cognitive decline. ${ }^{18}$ This instrument collects information from the patient and an appropriate informant, and takes into consideration other sources such as patients' medical records or information from other medical providers. These scales are developed to capture apathy in patients with cognitive impairment, and are not specific to AD. They employ different approaches and constructs, and assess and capture the apathy severity-spectrum, which can affect the prevalence rate. This variation in the assessment method affects treatment evaluation and patient enrollment for clinical trials.

\section{NeUrobiology OF APATHY IN AD}

Currently there is no guideline for treating apathy in $\mathrm{AD}$, even though the many neurobiological hypotheses linking apathy to neuronal correlates has led to the development of a multitude of psychotropic medications. ${ }^{5}$ The neurobiological hypotheses are based on the observation of patient groups with neurological or psychiatric impairment, suggesting that apathy arises from dysfunction of frontal-subcortical networks (namely amygdala, nucleus accumbens, and prefrontal cortex [PFC] $).{ }^{19-21}$ The three sub-domains of apathy, including dysfunctional emotion processing, dysfunctional cognitive activity, and reduced self-activation, arise from impairment of the orbital, dorsolateral, and medial PFC, respectively. Neuroimaging studies of $\mathrm{AD}$ patients have supported this hypothesis, correlating apathy with dysfunction in key regions of the PFC-basal ganglia circuitry, including orbitofrontal cortex, anterior cingulate cortex (ACC), inferior frontal cortex, caudate nucleus, and putamen nucleus. ${ }^{22-24}$ Dysfunction of these regions may have a neurochemical aetiology; that is, the putative mechanisms of $\mathrm{AD}$ pathogenesis (i.e. amyloid plaque formation, and hyper-phosphorylated tau aggregation) compromise neurotransmitter systems in the PFC-basal ganglia circuitry, giving rise to apathy symptoms. ${ }^{25}$ There are several important neurotransmitter-based hypotheses regarding the factors that exert an influence on the neuronal circuitry, including dopamine depletion, dysfunction of serotonin (5-HT), cholinergic and glutamate deficiency, and reduction of central GABA concentration. While a detailed review of the neurobiology of apathy is beyond the scope of the current work, we will highlight the main hypotheses.

The dopamine depletion hypothesis is supported by studies demonstrating reduced $\mathrm{D}_{2}$-like receptor density and lower levels of dopamine transporter in the striatum of $\mathrm{AD}$ patients with apathy. ${ }^{26-28}$ In one study, a lower level of dopamine transporters in the caudate and putamen correlated with a lack of interest and initiative. ${ }^{28}$ In light of the aforementioned neuroanatomical correlates these data seem to suggest that dopaminergic tone in the basal ganglia-ACCfrontal cortex circuitry, which is involved in motivated and goaldirected behaviour, is diminished in patients with $\mathrm{AD}$ and potentially mediates the apathetic behaviour. The link between disorders of central dopaminergic hypo-function (e.g. restless leg syndrome ${ }^{30}$ and extrapyramidal symptoms ${ }^{31}$ ) and apathy symptoms in AD provides additional evidence for diminished dopaminergic tone. Importantly, impairment of this system is associated with decline in cognitive functioning, mainly in attention and working memory. The dopamine hypotheses points to the use of dopaminergic agents or stimulants such s methylphenidate in treating apathy.

Serotonin, although controversial, tends to inhibit dopamine transmission. ${ }^{32}$ Dysfunction of the 5-HT system is widespread and varied in $\mathrm{AD}$ : 5-HT denervation of serotonin-releasing neurons is observed in the medial and dorsal raphe nuclei; levels of 5-HT and its primary metabolite are $40-80 \%$ lower compared to non-AD controls; synaptic densities of $5-\mathrm{HT}_{1,2,4,6}$ receptors are altered; and 5-HT transporter density is reduced by $20-40 \%$ in AD patients with apathy. ${ }^{33}$ These changes are present in the aforementioned neuroanatomical correlates of apathy. Additionally, correlation between 5-HT dysfunction with depressive symptoms in AD has been reported. ${ }^{33}$ For instance, one study linked 5HT dysfunction and depression severity with hypo-metabolism in the dorsolateral PFC. Given the considerable overlap between depression and apathy symptoms, the results of this study indirectly supports a role for 5-HT in apathetic behaviour. Based on considerable overlap of symptoms between depression and apathy, serotonergic and dopaminergic medications are reasonable treatment options for apathy in $\mathrm{AD}$. However, this seems counterintuitive when apathy assessment scales attempt to exclude patients with depression. Selective serotonin reuptake inhibitors (SSRIs) antidepressants are theoretically the treatment of choice under this hypothesis.

Evidence for the acetylcholine hypothesis suggests that primary concentrations of cholinergic neurons in the brain originate from the nucleus basalis (positioned between the frontal cortex and cingulate gyrus, ${ }^{34}$ two regions consistently correlated with apathy) that is significantly diminished in AD. The Glutamate hypothesis, on the other hand, emerges from therapeutic studies suggests a link between the glutamatergic system and apathy symptoms. Drug trials have demonstrated a role for glutamate receptor agonists in improving the negative symptoms of schizophrenia. ${ }^{35,36}$ In $\mathrm{AD}$, a double-blind RCT of mibampator, a glutamate receptor potentiator, significantly improved apathy in the treated group. ${ }^{37}$ In addition, recent trials on cholinesterase inhibitors suggest some efficacy on apathy symptoms in $\mathrm{AD}$ patients. ${ }^{38}$ The acetylcholine and glutamate hypotheses are the underlying reasons for using cholinesterase inhibitors or NMDA receptor agonists (e.g., memantine), respectively, for the management of apathy in AD. 
Regarding the GABA system impairment in $\mathrm{AD}$, studies report reduction of central GABA concentration (predominantly in latestage $\mathrm{AD}$ ) and up-regulation of $\mathrm{GABA}_{\mathrm{a}}$ receptors. ${ }^{39}$ Although one study did correlate GABA reduction and $\mathrm{GABA}_{\mathrm{a}}$ receptor upregulation with depressive symptoms, direct evidence correlating GABA dysfunction to apathy is lacking. ${ }^{40}$ Although direct evidence correlating norepinephrine (NE) with apathy is also lacking, the link between apathy and inattention, which is effectively treated by adrenergic agents in ADHD patients, lends support to NE as a basis for apathy in $\mathrm{AD} .{ }^{41}$ Mood stabilizers or other multi-action compounds are presumed to be the suitable agents under these hypotheses.

The putative neurochemical underpinnings of apathy and the considerable clinical overlap between depression and apathy have prompted the use of various psychotropic medications in apathetic $\mathrm{AD}$ patients. However, individual drug trials have yielded mixed results, probably because most studies have not considered the temporal relationship between neurochemical dysfunction and $\mathrm{AD}$ pathogenesis. For example, $5-\mathrm{HT}_{1 \mathrm{a}}$ receptors are up-regulated in mild cognitive impairment, ${ }^{42}$ but are significantly decreased in later stages of $\mathrm{AD}^{33}$ The drug's effects may therefore be stage-specific. In addition, many scales for apathy are based on older definitions, which largely focus on lack of motivation. Due to the established role of dopamine in the brain reward system, ${ }^{29}$ these scales may detect changes resulting from dopaminergic therapy, but may less reliably detect non-dopaminergic drugs' effects on the emotional and cognitive domains of apathy. Similarly, variable diagnostic criteria may have skewed the treatment effects. Furthermore, most studies targeted a single neurotransmitter system. Given the multiple neurochemical alterations in apathetic $\mathrm{AD}$ patients and the interconnectedness of neurotransmitter systems, ${ }^{30,43,44}$ drug therapy that has multiple mechanisms of action with tailored affinity may produce larger treatment effects.

\section{EVIDENCE FROM OPEN-LABEL TRIALS}

Twelve open-label trials were examined based on our search criteria for this meta-analysis. Five studies examined donepezil $;{ }^{45-49}$ three, rivastigmine; ${ }^{46,50,51}$ two, galantamine; ${ }^{46,52}$ one, memantine; ${ }^{46}$ one, gabapentin; ${ }^{53}$ one, citalopram $;{ }^{54}$ one, methylphenidate $;{ }^{55}$ and one, atypical antipsychotic. ${ }^{56}$ For these studies, average age ranged from 66 to 83 years. Average follow-up time was 31 weeks. Only one study examined apathy as a primary outcome (all others used the NPI-Apathy subscale). ${ }^{55}$ Most studies did not report a statistically significant change from baseline. A small, statistically significant improvement from baseline was observed in two of three rivastigmine trials, and one of three donepezil trials. A relatively large statistically significant improvement in AES was reported in the methylphenidate study $(\mathrm{n}=23$; baseline: 52.70 [6.7]; endpoint: 32.43 [5.7]; $\mathrm{p}<0.00010$.) Both galantamine trials reported a trend towards worsening apathy as examined by the NPI subscale, and one trial was statistically significant $[\mathrm{n}=33$; baseline: $0.38(0.2)$; endpoint: 1.44 (0.54); $\mathrm{p}=0.045$ ]. Basically, from open label studies we see mixed results, with heterogeneity in drugs used, sample, and assessment approaches, which renders generalizability difficult.

Recent systematic reviews highlighted the challenge in using any compound for management of apathy in $\mathrm{AD}^{57}$ and indirectly suggest that the treatment effect may be scale-dependent. ${ }^{58}$ Additionally, current systematic reviews of neuropsychiatric pharmacotherapy are lacking specificity for apathy outcome and are confounded by poor reporting methods. ${ }^{59-63}$ Taking into account of these limitations, experts have recently recommended that studies investigating apathy in neurodegenerative disease should A) look for the correlation between depression and apathy, B) look for treatment duration of 3 months or more, C) control for concomitant medications, D) control for history of stroke, E) and diagnostic assessment methods. ${ }^{64}$ Thus, we examined the available RCTs by taking into account these moderating variables.

\section{Material AND Methods}

\section{Eligibility criteria, Information sources \& Search}

On March 3, 2014, we conducted a search of the following databases for placebo-controlled RCTs (either parallel-group or cross-over): MEDLINE (1946-2014), EMBASE (1974-2014), PsycINFO (1597-2014), and the Cochrane Register of Controlled Trials (March 2014 issue). Additionally, we scanned http://www. clinicaltrials.gov and the reference lists of relevant systematic reviews. ${ }^{58,64}$ The search was subsequently updated on June 25, 2015.

To be included, studies had to report on adult patients ( $>=40$ years old) with Alzheimer's disease; trial an on-market, single-entity psychotropic medication; and used a validated instrument to measure apathy severity or presence. Studies merging data in the absence of duplicates were included.

\section{Study selections}

Two authors (AAS and MS) independently screened titles and abstracts with a priori set selection criteria. Subsequently, they independently screened the full-text of the possible studies to verify for the availability of data. In cases of disagreements, discussion followed until they were resolved by consensus with the senior author (GYRH).

\section{Data abstraction}

One author abstracted data including characteristics of study participants, type of intervention, and apathy outcome data. A second author checked the data extraction for accuracy.

\section{Bias, heterogeneity and effect size}

Both visual and qualitative methods were used to examine for publication bias. Heterogeneity's presence and magnitude was examined using the q-statistics and I-square. An aggregate random effect Hedge's g effect size estimate was calculated using the comprehensive meta-analysis to examine the global magnitude in group differences (treatment vs. control). ${ }^{65}$ In the absence of descriptive statistics (mean and standard deviation), when appropriate, p-values and sample size as reported by studies were used to generate the effect size. In the absence of reported exact non-significant p-values, alpha 0.06 (a liberal assumption) was used for analysis.

\section{RESUlts}

\section{Study selection}

The literature search for RCTs yielded 1193 citations from the search engines. Of the 678 unique abstracts, 49 were eligible for full-text review. Two authors (AAS and MS) independently reviewed and excluded articles, leaving 15 articles that met our entry criteria, which were included in our systematic review and meta-analysis (see Figure 1, flow diagram). 


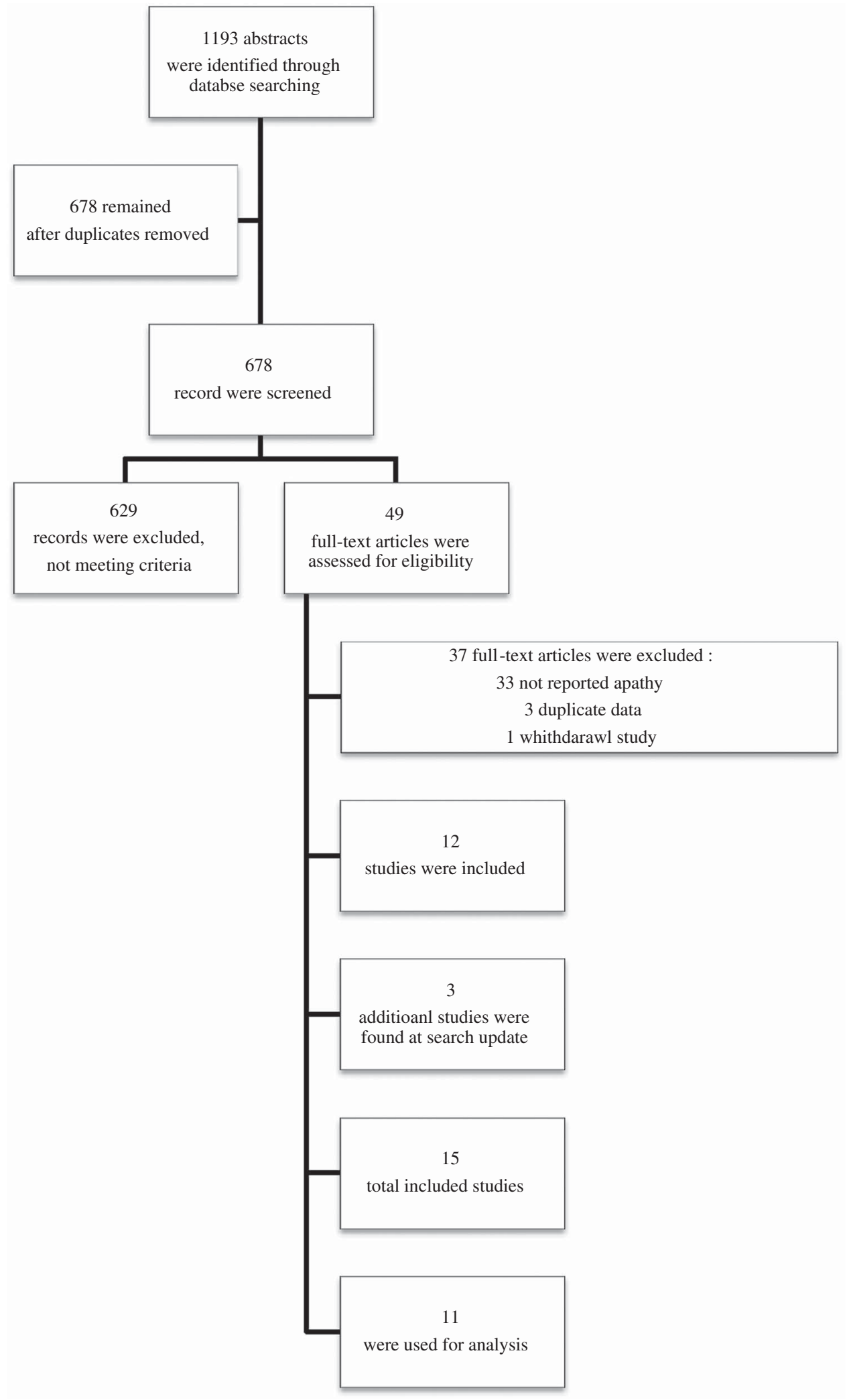

Figure 1: Flowchart showing study selection. 


\section{Study characteristics}

The amalgam of studies examined cholinesterase inhibitors, including three donepezil trials and one galantamine trial ${ }^{66}$ four memantine trials; ${ }^{67-70}$ three psycho-stimulant trials $;{ }^{41,71,72}$ two atypical antipsychotic trials, ${ }^{73,74}$ and two trials in which the active treatment was classified as "other.,"75,76 These fifteen RCTs included 2819 active compound treated and 2045 placebo-treated patients (total $=4864$ ). The average follow-up for each drug class varied. For the NMDA category, 24 and 28 weeks were the minimum and maximum duration of trials, respectively. For cholinesterase inhibitors, 12 and 24 weeks were the minimum and maximum median duration of treatment. For stimulant, 2 to 8 weeks was the treatment duration. For category "others," duration was 6 and 24 weeks.

Both severity of dementia and class of drug varied across trials. For studies reporting demographic values, the average age, MMSE score, and NPI total score of the treated patients ranged from 73.3 to $86,7.8$ to 24.1 , and 6.8 to 36.7 , respectively. Furthermore, global samples ranged from 22 to 2033, and overall included more female participants (percent male ranged from 17 to 50). The minimum sample size for treatment was 11 and the maximum was 1347; for placebo arms the minimum sample size was 13 and the maximum was 686 patients (Please see Table 1 for details).

\section{Data synthesis}

For cognitive enhancers (donepezil and galantamine), no significant apathy treatment effect was observed (Hedges' $\mathrm{g}=-0.055 ; 95 \% \mathrm{CI}$ : -0.322 to $0.213 ; \mathrm{P}$-value $=0.687$; $\mathrm{Q}$-value $=$ 17.378; $\mathrm{P}$-value $=0.001 ; \mathrm{I}^{2}=82.737 ; \mathrm{N}=4$.) The average donepezil dosage was $10 \mathrm{mg} /$ day (three studies) while galantamine dosage ranged between 16 and $32 \mathrm{mg} /$ day (an aggregate of data from trials). With the exception of one study, all studies used the NPI-apathy subscale as an outcome measure. These trials included mild to severe AD.

For NMDA category (memantine), a small and non-significant effect size estimate yielded in favour of treatment (Hedges' $\mathrm{g}=0.092 ; 95 \%$ CI: -0.134 to $0.318 ; \mathrm{P}$-value $=0.423$; Q-value $=$ $11.425 ; \mathrm{P}$-value $=0.010 ; \mathrm{I}^{2}=73.742 ; \mathrm{N}=4$.) All memantine trials reported the same average dosage $(20 \mathrm{mg} /$ day $)$, included moderate to severe AD, and used the NPI-apathy subscale.

For psycho-simulant, compared to placebo, a small and non-significant treatment effect yielded (Hedges' $\mathrm{g}=-0.063$; 95\% CI: -1.067 to $0.941 ; \mathrm{P}$-value $=0.903 ; \mathrm{Q}$-value $=12.486$; $\mathrm{P}$-value $=0.002 ; \mathrm{I}^{2}=83.982 ; \mathrm{N}=3$.) All stimulant trials included mild to moderate $\mathrm{AD}$ and used multiple scales, including NPI-apathy and FrSBe apathy subscale. This analysis included mixed drugs with non-comparable dosage.

For antipsychotics and "other" classes of drugs with antidepressant properties, not enough studies $(\mathrm{N}<3)$ were reported to allow analysis and support their use. Individual atypical antipsychotic studies did not support their use for apathy in AD..$^{73,74}$

The analysis for psycho-stimulants was underpowered due to limited patient enrolment in each arm of the trials, but not so for ChEI and NMDA. Given the limited number of studies included under each drug class, examination of heterogeneity or publication bias was not possible. However, under each drug class, informants provided a majority of the collateral information, and little, but not quantifiable discrepancy was observed in terms of the type of studies (RCT, or retrospective data from RCT's), or whether the study was primarily or secondarily investigating apathy (Please see Figure 2 for details).

\section{DiscusSION AND CONCLUSION}

To our knowledge this is the first meta-analysis examining the effect of multiple compounds for management of apathy in AD. This meta-analysis examined fifteen studies and found limited evidence to support the use of any of the medications we examined for management of apathy in AD. However, significant heterogeneity was observed under each drug class that we could not explain given the limited number of studies.

We speculate that the lack of an effect could be due to the clinical heterogeneity in the sample included. For example, AD severity ranged from early stage to severe. Thus, future studies should focus on one stage for more homogeneous effect. Additionally, the lack of an effect could be due to methodological issues. For example, sample size, attrition, using the last observation carried forward, ${ }^{77}$ or use of a modified intention-to-treat approaches,${ }^{78}$ could have masked treatment effect. Unfortunately, because of limited number of studies under each drug class, further analysis and controlling for these factors were not possible. Moreover, we excluded many controlled trials because they did not report the NPI breakdown on apathy sub-score (we did not contact authors for pertinent information). The results may also be confounded by publication bias, and we have not examined the effect of compounds' affinity for specific neurotransmitter(s) in order to provide the neurobiological underpinning for specific treatment approaches. Also, our means aggregate did not examine the proportion of patients showing benefit versus no change or deterioration. Further assessment of clinical response and tolerance with respect to this difference is warranted, since this can vary within the same class of drugs. ${ }^{79}$

\section{Conclusion}

\section{Direction for future research}

The inability of current pharmacotherapy to provide a clinically meaningful effect on apathy may be a result of the drugs' ineffectiveness. However, owing to methodological limitations, the drugs' apparent ineffectiveness may be an artifact of poor trial designs that we have not systematically examined. ${ }^{80}$ In support of a poor trial design hypothesis, we postulate methodological issues that might account for the lack of observable treatment effect on apathy. First, all trials used either NPI-apathy sub-score or AES to assess apathy; none use the newly proposed diagnostic criteria for apathy in AD. While NPI-apathy and AES are the most widely used and psychometrically robust apathy scales, ${ }^{81}$ they largely define apathy as a lack of motivation; therefore, they may not fully capture the pleomorphic nature of apathy in AD. Other scales that are based on clearly defined and validated diagnostic criteria ${ }^{12}$ that also differentiate depression from apathy, such as the apathy inventory (AI) ${ }^{16}$ or the expanded NPI (NPI-C), ${ }^{82}$ may better distinguish the apathetic $\mathrm{AD}$ patients' emotional, cognitive, and behavioral deficits.

\section{Direction for practice}

Given the limited efficacy of the available drug options, we don't see supporting evidence for pharmacotherapy as a first-line treatment for apathy in AD. Several types of non-drug interventions have demonstrated a positive effect in at least a few trials, ${ }^{83}$ which could represent potentially safer alternatives. 
Table 1: Descriptive of the included RCTs-Baseline characteristics $(\mathrm{N}=15)$

\begin{tabular}{|c|c|c|c|c|c|c|c|c|c|c|c|c|c|}
\hline \multirow[b]{2}{*}{ Study ID } & \multirow{2}{*}{$\begin{array}{c}\text { Treatment } \\
\text { Dosage }\end{array}$} & \multirow[b]{2}{*}{$\mathbf{n}$} & \multicolumn{4}{|c|}{$\begin{array}{l}\text { Baseline Characteristics } \\
\text { (Treated group) }\end{array}$} & \multirow[b]{2}{*}{$\begin{array}{c}\text { Follow-up } \\
\text { (weeks) }\end{array}$} & \multicolumn{2}{|c|}{$\begin{array}{c}\text { Attrition } \\
(\%)\end{array}$} & \multirow{2}{*}{$\begin{array}{c}\begin{array}{c}\text { Depression } \\
\text { assessment }\end{array} \\
(\text { Yes } / N R)\end{array}$} & \multirow{2}{*}{$\begin{array}{c}\begin{array}{c}\text { Patient } \\
\text { Type }\end{array} \\
\text { (Environment) }\end{array}$} & \multirow{2}{*}{$\begin{array}{c}\text { AD } \\
\text { Severity }\end{array}$} & \multirow{2}{*}{$\begin{array}{c}\text { Apathy } \\
\text { Measure }\end{array}$} \\
\hline & & & Male & Age & MMSE & NPI & & $P l c$ & $T x t$ & & & & \\
\hline $\begin{array}{l}A r a k i \\
2014\end{array}$ & $\begin{array}{l}\text { Memantine } \\
(20 \mathrm{mg} / \text { day })\end{array}$ & 37 & $30 \%$ & $77.9(9.8)$ & NR & NR & 24 & 28 & 37 & Yes & Outpatient & Mod-Sev & NPI-apathy \\
\hline $\begin{array}{l}\text { Cummings } \\
2006\end{array}$ & $\begin{array}{l}\text { Memantine } \\
(20 \mathrm{mg} / \text { day })\end{array}$ & 403 & $37 \%$ & $75.5(8.45)$ & $9.9(3.13)$ & 13.7 (14.7) & 24 & 25 & 15 & Yes & Multicentre & Mod-Sev & NPI-apathy \\
\hline $\begin{array}{r}\text { Frakey } \\
2012\end{array}$ & $\begin{array}{l}\text { Modafinil } \\
\quad(200 \mathrm{mg} / \text { day })\end{array}$ & 22 & NR & $75.27(8.34)$ & NR & $\mathrm{NR}$ & 8 & 0 & 10 & NR & $\begin{array}{l}\text { Memory and Aging } \\
\text { program }\end{array}$ & Mil-Mod & FrSBe-apathy \\
\hline $\begin{array}{l}\text { Gauthier } \\
2002 * *\end{array}$ & $\begin{array}{l}\text { Donepezil } \\
\quad(10 \mathrm{mg} / \text { day })\end{array}$ & 290 & $39 \%$ & $73.3(\mathrm{NR})$ & $11.72(5.96)$ & $19.55(24.86)$ & 24 & 14 & 16 & Yes & Multicentre & Mod-Sev & NPI-apathy \\
\hline $\begin{array}{l}\text { Gauthier } \\
2008\end{array}$ & $\begin{array}{l}\text { Memantine } \\
(20 \mathrm{mg} / \text { day })\end{array}$ & 1826 & $32.8 \%$ & $76.2(8.1)$ & $12.3(4.2)$ & $15.9(14.7)$ & $24-28$ & - & - & Yes & Multicentre & Mod-Sev & NPI-apathy \\
\hline $\begin{array}{l}\text { Herrmann } \\
2005\end{array}$ & $\begin{array}{c}\text { Galantamine } \\
(16-32 \mathrm{mg} / \text { day })\end{array}$ & 2033 & $38 \%$ & $76.5(7.7)$ & $18.2(3.9)$ & $11.46(12.91)$ & $12-24$ & - & - & Yes & Multicentre & Mil-Mod & NPI-apathy \\
\hline $\begin{array}{l}\text { Herrmann } \\
2008\end{array}$ & $\begin{array}{c}\text { Methylphenidate } \\
(20 \mathrm{mg} / \text { day })\end{array}$ & 13 & $46 \%$ & $77.9(7.8)$ & $19.9(4.7)$ & $15.5(11.30)$ & 2 & 8 & 15 & $\mathrm{NR}$ & Outpatient & Mil-Mod & NPI-apathy \\
\hline $\begin{array}{l}\text { Herrmann } \\
2013\end{array}$ & $\begin{array}{l}\text { Memantine } \\
(20 \mathrm{mg} / \text { day })\end{array}$ & 369 & 42.3 & 74.7 (7.9) & $11.9(3.1)$ & $30.9(14.8)$ & 24 & 17 & 17 & NR & Multicentre & Mod-Sev & NPI-apathy \\
\hline $\begin{array}{c}\text { Mohs } \\
2009\end{array}$ & $\begin{array}{l}\text { Atomoxetine } \\
\quad(63.9 \mathrm{mg} / \text { day })\end{array}$ & 92 & NR & NR & $20.3(4.5)$ & $6.8(14.1)$ & 24 & 19 & 22 & Yes & Multicentre & Mld-Mod & NPI-apathy \\
\hline $\begin{array}{l}\text { Paleacu } \\
2008^{*}\end{array}$ & $\begin{array}{l}\text { Quetiapine } \\
\quad(200 \mathrm{mg} / \text { day })\end{array}$ & 40 & $35 \%$ & $82.2(6.4)$ & $14.5(6.3)$ & NR & 6 & 40 & 25 & Yes & $N S$ & $N S$ & NPI-apathy \\
\hline $\begin{array}{l}\text { Peskind } \\
2005^{* * *}\end{array}$ & $\begin{array}{l}\text { Propranolol } \\
\text { (106 mg/day) }\end{array}$ & 31 & $18 \%$ & $86(8)$ & $7.8(7.5)$ & $25.5(15.6)$ & 6 & 73 & 35 & Yes & Outpatient & $N S$ & NPI-apathy \\
\hline $\begin{array}{l}\text { Rosenberg } \\
2013\end{array}$ & $\begin{array}{c}\text { Methylphenidate } \\
(20 \mathrm{mg} / \mathrm{day})\end{array}$ & 60 & $41 \%$ & $78(8)$ & $19(5)$ & $15(6)$ & 6 & 7 & 3 & Yes & Multicenter & Mil-Mod & $\begin{array}{l}\text { AES, NPI- } \\
\text { apathy }\end{array}$ \\
\hline $\begin{array}{l}\text { Seltzer } \\
2004\end{array}$ & $\begin{array}{l}\text { Donepezil } \\
\quad(10 \mathrm{mg} / \text { day })\end{array}$ & 153 & $50 \%$ & $73.3(9.6)$ & $24.1(1.7)$ & NR & 24 & 19 & 27 & Yes & Multicentre & Mild & $A S$ \\
\hline $\begin{array}{l}\text { Streim } \\
2008 \\
\end{array}$ & $\begin{array}{l}\text { Aripiprazole } \\
\quad(2-15 \mathrm{mg} / \text { day })\end{array}$ & 256 & $22 \%$ & 83 (NR) & $13.94(8.63)$ & $36.74(30.49)$ & 10 & 49 & 34 & Yes & Inpatients & $N S$ & NPI-apathy \\
\hline $\begin{array}{l}\text { Tariot } \\
2002\end{array}$ & $\begin{array}{l}\text { Donepezil } \\
\quad(10 \mathrm{mg} / \text { day })\end{array}$ & 208 & $17 \%$ & 85.4 (NR) & $14.4(5.4)$ & $21.0(14.5)$ & 24 & 26 & 18 & Yes & Multicentre & $N S$ & NPI-apathy \\
\hline
\end{tabular}

NPI-NH: Neuropsychiatric Inventory-Nursing Home version; AES: Apathy Examination Scale; SIB: Severe Impairment Battery; ADCS-ADL: Alzheimer's Disease Co-operative Study - Activities of Daily Living Inventory; FrSBe: Frontal Systems Behavior Scale; ADAS-Cog: Alzheimer's Disease Assessment Scale - Cognitive; CGIC: Clinical Global Impression of Change; NR: Not reported. Scores for age, MMSE, and NPI are in mean and (SD).

*mean age and \%male is based on the full sample;

**Included patient data from Feldman et al $2001^{85}$

***MMSE Score is for trial completers only. NR: not reported; NS: Not specified. Depression assessment was defined by using any scale that report on depressive symptoms 


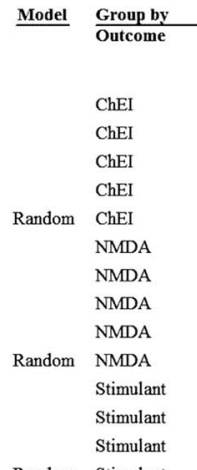

Random Stimulant

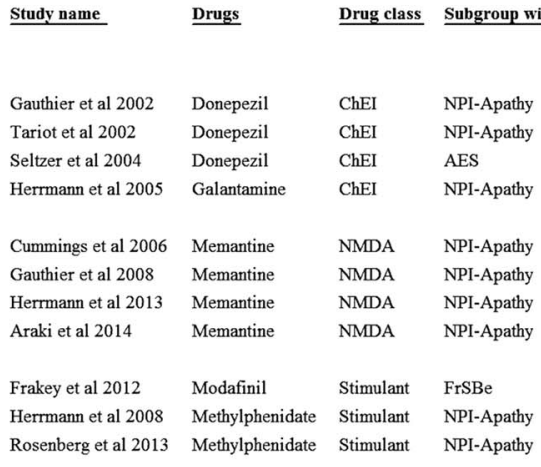

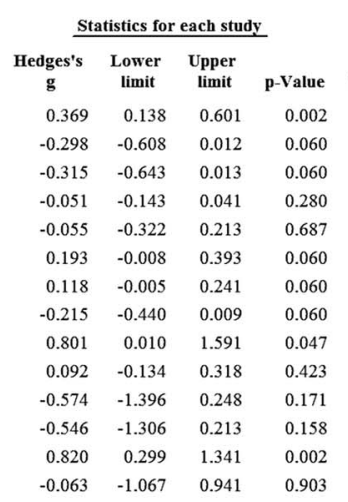

\begin{tabular}{cc}
\multicolumn{2}{c}{ Sample size } \\
Treatment & Placebo \\
144 & 146 \\
82 & 78 \\
96 & 57 \\
1347 & 686 \\
1669 & 967 \\
193 & 189 \\
546 & 476 \\
151 & 155 \\
12 & 13 \\
902 & 833 \\
11 & 11 \\
13 & 13 \\
29 & 31 \\
53 & 55
\end{tabular}

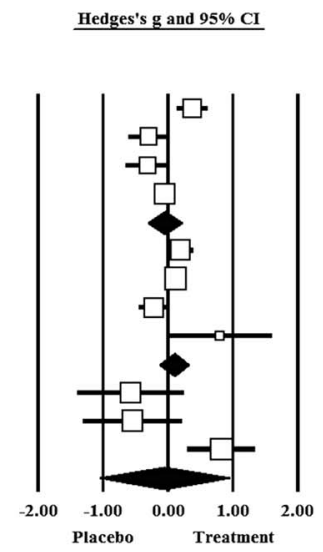

Figure 2: Forest plot showing RCTs examining the effect of pharmacological compounds on apathy in AD. AE: Apathy evaluation scale; ChEI: Cholinesterase inhibitor; FrSBe: Frontal Systems Behavior Scale; NMDA: N-Methyl D-Aspartate agonist; NPI: Neuropsychiatric Inventory. Gauthier et al. 2002 used data from Feldman et al $2001 .{ }^{85}$

Where a patient with severe apathy fails adequate trials of multiple non-pharmacological treatments, a cautiously monitored trial of add-on methylphenidate or a switch to rivastigmine is reasonable. The methylphenidate RCT reported by Rosenberg et al. demonstrated the largest effect size. While no rivastigmine RCT fit our eligibility criteria in our current analysis, this compound demonstrated the largest effect on apathy in open label studies. ${ }^{84}$ Consistent with a current view of the literature, ${ }^{58}$ we recognize that the results of the methylphenidate RCT must be replicated in a larger RCT using validated diagnostic and assessment tools before the drug can be more widely recommended.

\section{ACKNOWLEDGEMENTS AND FUNDING}

We wish to acknowledge the reviewers' diligent revision of this work and comments on content.

\section{Disclosures}

AS received post-doctoral fellowships from the Alzheimer's Society of Canada and Canadian Consortium on Neurodegeneration in Aging (ASC/CCNA). GYRH received funds as a site investigator for clinical trials sponsored by TauRx, Roche, Eli Lilly, AstraZeneca, Biogen, Merck, and Genentech; participated in educational program development sponsored by Merck. MS has no disclosures.

\section{Statement OF AUTHORSHIP}

Study concept and design: MS, AS; acquisition, analysis, and interpretation of data: all authors; drafting of the manuscript: MS, AS; critical revision of the manuscript for intellectual content: AS, GYRH; statistical analyses: AS; supervision: GYRH.

\section{REFERENCES}

1. Starkstein SE, Petracca G, Chemerinski E, Kremer J. Syndromic validity of apathy in Alzheimer's disease. Am J Psychiatry. 2001;158(6):872-7.

2. Mega MS, Cummings JL, Fiorello T, Gornbein J. The spectrum of behavioral changes in Alzheimer's disease. Neurology. 1996; 46(1):130-5.

3. Starkstein SE, Jorge R, Mizrahi R, Robinson RG. A prospective longitudinal study of apathy in Alzheimer's disease. J Neurol Neurosurg Psychiatry. 2006;77(1):8-11.
4. Freels S, Cohen D, Eisdorfer C, et al. Functional status and clinical findings in patients with Alzheimer's disease. J Gerontology. 1992;47(6):M177-82.

5. Guimaraes HC, Levy R, Teixeira AL, Beato RG, Caramelli P. Neurobiology of apathy in Alzheimer's disease. Arq Neuropsiquiatr. 2008;66(2B):436-43.

6. Apostolova LG, Cummings JL. Neuropsychiatric manifestations in mild cognitive impairment: a systematic review of the literature. Dement Geriatr Cogn Disord. 2008;25(2):115-26.

7. Vilalta-Franch J, Calvo-Perxas L, Garre-Olmo J, Turro-Garriga O, Lopez-Pousa S. Apathy syndrome in Alzheimer's disease epidemiology: prevalence, incidence, persistence, and risk and mortality factors. J Alzheimers Dis. 2013;33(2):535-43.

8. Marin RS. Apathy: a neuropsychiatric syndrome. J Neuropsychiatry Clin Neurosci. 1991;3(3):243-54.

9. Starkstein SE, Ingram L, Garau ML, Mizrahi R. On the overlap between apathy and depression in dementia. J Neurol Neurosurg Psychiatry. 2005;76(8):1070-4.

10. Starkstein SE, Leentjens AF. The nosological position of apathy in clinical practice. J Neurol Neurosurg Psychiatry. 2008;79(10):1088-92.

11. Starkstein SE, Manes F. Apathy and depression following stroke. CNS Spectr. 2000;5(3):43-50.

12. Robert $\mathrm{P}$, Onyike CU, Leentjens AF, et al. Proposed diagnostic criteria for apathy in Alzheimer's disease and other neuropsychiatric disorders. Eur Psychiatry. 2009;24(2):98-104.

13. Marin RS, Biedrzycki RC, Firinciogullari S. Reliability and validity of the Apathy Evaluation Scale. Psychiatry Res. 1991;38(2):143-62.

14. Lueken U, Seidl U, Volker L, Schweiger E, Kruse A, Schroder J. Development of a short version of the Apathy Evaluation Scale specifically adapted for demented nursing home residents. Am J Geriatr Psychiatry. 2007;15(5):376-85.

15. Starkstein SE, Mayberg HS, Preziosi TJ, Andrezejewski P, Leiguarda R, Robinson RG. Reliability, validity, and clinical correlates of apathy in Parkinson's disease. J Neuropsychiatry Clin Neurosci. 1992;4(2):134-9.

16. Robert $\mathrm{PH}$, Clairet S, Benoit $\mathrm{M}$, et al. The apathy inventory: assessment of apathy and awareness in Alzheimer's disease, Parkinson's disease and mild cognitive impairment. Int J Geriatr Psychiatry. 2002:17(12):1099-105.

17. Cummings JL, Mega M, Gray K, Rosenbergthompson S, Carusi DA, Gornbein J. The Neuropsychiatric Inventory - Comprehensive Assessment of Psychopathology in Dementia. Neurology. 1994;44(12):2308-14.

18. Strauss ME, Sperry SD. An informant-based assessment of apathy in Alzheimer disease. Neuropsychiatry Neuropsychol Behav Neurol. 2002;15(3):176-83.

19. Theleritis C, Politis A, Siarkos K, Lyketsos CG. A review of neuroimaging findings of apathy in Alzheimer's disease. Int Psychogeriatr. 2014;26(2):195-207. 
20. Levy R, Dubois B. Apathy and the functional anatomy of the prefrontal cortex-basal ganglia circuits. Cereb Cortex. 2006;16(7):916-28.

21. Craig AH, Cummings JL, Fairbanks L, et al. Cerebral blood flow correlates of apathy in Alzheimer disease. Arch Neurol. 1996; 53(11):1116-20.

22. Lanctot KL, Moosa S, Herrmann N, et al. A SPECT study of apathy in Alzheimer's disease. Dement Geriatr Cogn Disord. 2007; 24(1):65-72.

23. Marshall GA, Monserratt L, Harwood D, Mandelkern M, Cummings JL, Sultzer DL. Positron emission tomography metabolic correlates of apathy in Alzheimer disease. Arch Neurol. 2007;64(7):1015-20.

24. Bruen PD, McGeown WJ, Shanks MF, Venneri A. Neuroanatomical correlates of neuropsychiatric symptoms in Alzheimer's disease. Brain. 2008;131(Pt 9):2455-63.

25. Cummings JL. Toward a molecular neuropsychiatry of neurodegenerative diseases. Ann Neurol. 2003;54(2):147-54.

26. Mitchell RA, Herrmann N, Lanctot KL. The role of dopamine in symptoms and treatment of apathy in Alzheimer's disease. CNS neuroscience \& therapeutics. 2011;17(5):411-27.

27. Lanctot KL, Herrmann N, Black SE, et al. Apathy associated with Alzheimer disease: use of dextroamphetamine challenge. Am J Geriatr Psychiatry. 2008;16(7):551-7.

28. David R, Koulibaly M, Benoit M, et al. Striatal dopamine transporter levels correlate with apathy in neurodegenerative diseases A SPECT study with partial volume effect correction. Clinical. Neurol Neurosurg. 2008;110(1):19-24.

29. Schultz W. Dopamine neurons and their role in reward mechanisms. Curr Opin Neurobiol. 1997;7(2):191-7.

30. Smith GS, Kramer E, Ma Y, et al. Cholinergic modulation of the cerebral metabolic response to citalopram in Alzheimer's disease. Brain. 2009;132(Pt 2):392-401.

31. Starkstein SE, Merello M, Brockman S, Bruce D, Petracca G, Power BD. Apathy predicts more severe parkinsonism in Alzheimer's disease. Am J Geriatr Psychiatry. 2009;17(4):291-8.

32. Sasaki-Adams DM, Kelley AE. Serotonin-dopamine interactions in the control of conditioned reinforcement and motor behavior. Neuropsychopharmacology : official publication of the American College of Neuropsychopharmacology. 2001;25(3):440-52.

33. Rodriguez JJ, Noristani HN, Verkhratsky A. The serotonergic system in ageing and Alzheimer's disease. Prog Neurobiol. 2012; 99(1):15-41.

34. Cummings JL, Back C. The cholinergic hypothesis of neuropsychiatric symptoms in Alzheimer's disease. Am J Geriatr Psychiatry. 1998; 6(2 Suppl 1):S64-78.

35. Zink M, Correll CU. Glutamatergic agents for schizophrenia: current evidence and perspectives. Expert Rev Clin Pharmacol. 2015; 8(3):335-52.

36. Gibert-Rahola J, Villena-Rodriguez A. Glutamatergic drugs for schizophrenia treatment. Actas Esp Psiquiatr. 2014;42(5): 234-41.

37. Chappell AS, Gonzales C, Williams J, Witte MM, Mohs RC, Sperling R. AMPA potentiator treatment of cognitive deficits in Alzheimer disease. Neurology. 2007;68(13):1008-12.

38. Cummings JL. Cholinesterase inhibitors: A new class of psychotropic compounds. Am J Psychiatry. 2000;157(1):4-15.

39. Lanctot KL, Herrmann $\mathrm{N}$, Mazzotta $\mathrm{P}$, Khan LR, Ingber $\mathrm{N}$. GABAergic function in Alzheimer's disease: evidence for dysfunction and potential as a therapeutic target for the treatment of behavioural and psychological symptoms of dementia. Can J Psychiatry. 2004;49(7):439-53.

40. Garcia-Alloza M, Tsang SW, Gil-Bea FJ, et al. Involvement of the GABAergic system in depressive symptoms of Alzheimer's disease. Neurobiol Aging. 2006;27(8):1110-7.

41. Herrmann N, Rothenburg LS, Black SE, et al. Methylphenidate for the treatment of apathy in Alzheimer disease: prediction of response using dextroamphetamine challenge. J Clin Psychopharmacol. 2008;28(3):296-301.

42. Truchot L, Costes SN, Zimmer L, et al. Up-regulation of hippocampal serotonin metabolism in mild cognitive impairment. Neurology. 2007;69(10):1012-7.

43. Zhang L, Zhou FM, Dani JA. Cholinergic drugs for Alzheimer's disease enhance in vitro dopamine release. Molecular Pharmacol. 2004;66(3):538-44.
44. Garcia-Alloza M, Gil-Bea FJ, Diez-Ariza M, et al. Cholinergicserotonergic imbalance contributes to cognitive and behavioral symptoms in Alzheimer's disease. Neuropsychologia. 2005; 43(3):442-9.

45. Lopez OL, Mackell JA, Sun Y, et al. Effectiveness and safety of donepezil in Hispanic patients with Alzheimer's disease: a 12-week open-label study. J Natl Med Assoc. 2008;100(11):1350-8.

46. Cumbo E, Ligori LD. Differential effects of current specific treatments on behavioral and psychological symptoms in patients with Alzheimer's disease: a 12-month, randomized, open-label trial. J Alzheimers Dis. 2014;39(3):477-85.

47. Rosenblatt A, Gao J, Mackell J, Richardson S. Efficacy and safety of donepezil in patients with Alzheimer's disease in assisted living facilities. Am J Alzheimers Dis Other Demen. 2010;25(6):483-9.

48. Sakka P, Tsolaki M, Hort J, et al. Effectiveness of open-label donepezil treatment in patients with Alzheimer's disease discontinuing memantine monotherapy. Curr Med Res Opin. 2007;23(12):3153-65.

49. Yatabe Y, Hashimoto M, Kaneda K, et al. Efficacy of increasing donepezil in mild to moderate Alzheimer's disease patients who show a diminished response to $5 \mathrm{mg}$ donepezil: a preliminary study. Psychogeriatrics. 2013;13(2):88-93.

50. Cummings JL, Koumaras B, Chen M, Mirski D, Rivastigmine Nursing Home Study T. Effects of rivastigmine treatment on the neuropsychiatric and behavioral disturbances of nursing home residents with moderate to severe probable Alzheimer's disease: a 26-week, multicenter, open-label study. Am J Geriatr Pharmacother. 2005;3(3):137-48.

51. Chan CF, Chan WC, Li SW. Efficacy and safety of rivastigmine in the treatment of behavioural and psychological symptoms in Chinese dementia patients: An open-label study.

52. Chu LW, Yik PY, Mok W, Chung CP. A 2-year open-label study of galantamine therapy in Chinese Alzheimer's disease patients in Hong Kong. Int J Clin Pract. 2007;61(3):403-10.

53. Moretti R, Torre P, Antonello RM, Cazzato G, Bava A. Gabapentin for the treatment of behavioural alterations in dementia: preliminary 15-month investigation. Drugs Aging. 2003; 20(14):1035-40.

54. Scharre DW, Davis RA, Warner JL, Chang SI, Beversdorf DQ. A pilot open-label trial of citalopram for restless activity and aberrant motor behaviors in Alzheimer disease. Am J Geriatr Psychiatry. 2003;11(6):687-91.

55. Padala PR, Burke WJ, Shostrom VK, et al. Methylphenidate for apathy and functional status in dementia of the Alzheimer type. Am J Geriatr Psychiatry. 2010;18(4):371-4.

56. Street JS, Clark WS, Kadam DL, et al. Long-term efficacy of olanzapine in the control of psychotic and behavioral symptoms in nursing home patients with Alzheimer's dementia. Int J Geriatr Psychiatry. 2001;16(Suppl 1):S62-70.

57. Rea R, Carotenuto A, Fasanaro AM, Traini E, Amenta F. Apathy in Alzheimer's disease: any effective treatment? ScientificWorldJournal. 2014;2014:421385.

58. Lanctot KL, Aguera-Ortiz L, Brodaty H, et al. Apathy associated with neurocognitive disorders: recent progress and future directions. Alzheimers Dement. 2016; Jun 27 [Epub ahead of print].

59. Rodda J, Morgan S, Walker Z. Are cholinesterase inhibitors effective in the management of the behavioral and psychological symptoms of dementia in Alzheimer's disease? A systematic review of randomized, placebo-controlled trials of donepezil, rivastigmine and galantamine. Int Psychogeriatr. 2009;21(5):813-24.

60. Wynn ZJ, Cummings JL. Cholinesterase inhibitor therapies and neuropsychiatric manifestations of Alzheimer's disease. Dement Geriatr Cogn Disord. 2004;17(1-2):100-8.

61. Drijgers RL, Aalten P, Winogrodzka A, Verhey FR, Leentjens AF. Pharmacological treatment of apathy in neurodegenerative diseases: a systematic review. Dement Geriatr Cogn Disord. 2009;28(1):13-22.

62. Henry G, Williamson D, Tampi RR. Efficacy and tolerability of antidepressants in the treatment of behavioral and psychological symptoms of dementia, a literature review of evidence. Am J Alzheimers Dis Other Demen. 2011;26(3):169-83.

63. Berman K, Brodaty H, Withall A, Seeher K. Pharmacologic treatment of apathy in dementia. Am J Geriatr Psychiatry. 2012;20(2):104-22. 
64. Cummings J, Friedman JH, Garibaldi G, et al. Apathy in Neurodegenerative Diseases: Recommendations on the Design of Clinical Trials. J Geriatr Psychiatry Neurol. 2015;28(3):159-73.

65. Borenstein M, Hedges L, Higgins J, H. R. Comprehensive Metaanalysis, 2 ed. Englewood, NJ: Biostat; 2005.

66. Herrmann N, Rabheru K, Wang J, Binder C. Galantamine treatment of problematic behavior in Alzheimer disease: post-hoc analysis of pooled data from three large trials. Am J Geriatr Psychiatry. 2005;13(6):527-34.

67. Araki T, Wake R, Miyaoka T, et al. The effects of combine treatment of memantine and donepezil on Alzheimer's disease patients and its relationship with cerebral blood flow in the prefrontal area. Int J Geriatr Psychiatry. 2014;29(9):881-9.

68. Herrmann N, Gauthier S, Boneva N, Lemming OM, Investigators. A randomized, double-blind, placebo-controlled trial of memantine in a behaviorally enriched sample of patients with moderateto-severe Alzheimer's disease. Int Psychogeriatr. 2013;25(6):919-27.

69. Gauthier S, Loft H, Cummings J. Improvement in behavioural symptoms in patients with moderate to severe Alzheimer's disease by memantine: a pooled data analysis. Int $\mathbf{J}$ Geriatr Psychiatry. 2008;23(5):537-45.

70. Cummings JL, Schneider E, Tariot PN, Graham SM, Memantine MEMMDSG. Behavioral effects of memantine in Alzheimer disease patients receiving donepezil treatment. Neurology. 2006;67(1):57-63.

71. Frakey LL, Salloway S, Buelow M, Malloy P. A randomized, doubleblind, placebo-controlled trial of modafinil for the treatment of apathy in individuals with mild-to-moderate Alzheimer's disease. J Clin Psychiatry. 2012;73(6):796-801.

72. Rosenberg PB, Lanctot KL, Drye LT, et al. Safety and efficacy of methylphenidate for apathy in Alzheimer's disease: a randomized, placebo-controlled trial. J Clin Psychiatry. 2013;74(8):810-6.

73. Paleacu D, Barak Y, Mirecky I, Mazeh D. Quetiapine treatment for behavioural and psychological symptoms of dementia in Alzheimer's disease patients: a 6-week, double-blind, placebo-controlled study. Int J Geriatr Psychiatry. 2008;23(4):393-400.

74. Streim JE, Porsteinsson AP, Breder CD, et al. A randomized, doubleblind, placebo-controlled study of aripiprazole for the treatment of psychosis in nursing home patients with Alzheimer disease. Am J Geriatr Psychiatry. 2008;16(7):537-50.
75. Mohs RC, Shiovitz TM, Tariot PN, Porsteinsson AP, Baker KD, Feldman PD. Atomoxetine augmentation of cholinesterase inhibitor therapy in patients with Alzheimer disease: 6-month, randomized, double-blind, placebo-controlled, parallel-trial study. Am J Geriatr Psychiatry. 2009;17(9):752-9.

76. Peskind ER, Tsuang DW, Bonner LT, et al. Propranolol for disruptive behaviors in nursing home residents with probable or possible Alzheimer disease: a placebo-controlled study. Alzheimer Dis Assoc Disord. 2005;19(1):23-8.

77. Molnar FJ, Hutton B, Fergusson D. Does analysis using "last observation carried forward" introduce bias in dementia research? Cmaj. 2008;179(8):751-3.

78. Liberati A, Altman DG, Tetzlaff J, et al. The PRISMA statement for reporting systematic reviews and meta-analyses of studies that evaluate health care interventions: explanation and elaboration. PLoS Med. 2009;6(7):e1000100.

79. Sepehry AA, Lee PE, Hsiung GYR, Jacova C. Stay the course-is it justified? Lancet. 2012;379(9812):220.

80. Schneider LS, Mangialasche F, Andreasen N, et al. Clinical trials and late-stage drug development for Alzheimer's disease: an appraisal from 1984 to 2014. J Intern Med. 2014;275(3):251-83.

81. Clarke DE, Ko JY, Kuhl EA, van Reekum R, Salvador R, Marin RS. Are the available apathy measures reliable and valid? A review of the psychometric evidence. J Psychosom Res. 2011;70(1): 73-97.

82. de Medeiros K, Robert P, Gauthier S, et al. The Neuropsychiatric Inventory-Clinician rating scale (NPI-C): reliability and validity of a revised assessment of neuropsychiatric symptoms in dementia. Int Psychogeriatr. 2010;22(6):984-94.

83. Brodaty $\mathrm{H}$, Burns K. Nonpharmacological management of apathy in dementia: a systematic review. Am J Geriatr Psychiatry. 2012; 20(7):549-64

84. Gauthier S, Juby A, Dalziel W, Rehel B, Schecter R, investigators E. Effects of rivastigmine on common symptomatology of Alzheimer's disease (EXPLORE). Curr Med Res Opin. 2010; 26(5):1149-60.

85. Feldman H, Gauthier S, Hecker J, et al. A 24-week, randomized, double-blind study of donepezil in moderate to severe Alzheimer's disease. Neurology. 2001;57(4):613-20. 